\title{
PRAKTIK FIKIH KESEHARIAN MINORITAS MUSLIM DI BALI
}

\author{
Fathorrahman $^{\mathrm{a}, 1, *}$, Saifuddin ${ }^{\mathrm{b}, 2}$ \\ ${ }^{a b}$ UIN Sunan Kalijaga, Yogyakarta ,55281, Indonesia \\ ${ }^{1}$ fathur_2000@yahoo.com *; ${ }^{2}$ saifshuinsuka@gmail.com;
}

ARTICLE INFO

Article history:

Received : 2020-07-21

Revised : 2020-07-28

Accepted :2020-12-21

Keywords:

Adaptation,

Harmony,

Tolerance

Kata kunci:

Adaptasi,

Kerukunan,

Toleransi.

\section{ABSTRACT}

This paper explored a daily fiqh practice or, more precisely, the practice of Islam among Muslim minorities in Bali, which is transformed into an adaptable form of religious diversity promoting harmony. In the midst of the strong domination of Hindu custom and the acts of violence by few Muslims in Indonesia, the Balinese Muslim community strived to manifest Islamic teachings (fiqh) in daily life having tolerant and moderate. Through two problems such as; how is the religious adaptation pattern of minority Muslim communities in Bali? How do Muslim communities establish inter-religious harmony as a manifestation of their daily fiqh? This study attempted to analyze it based on maqashid sharia theory. As for supporting data collection, this paper used field research using interviews and observations. The finding indicated that there were interesting patterns of religious social relations occurred in the daily practice of Muslim minorities in expressing their Islamic teachings in the public area. Muslims in Bali are able to appraise their religious teachings and adapt with the surrounding community, which was socio-anthropologically dominated by the Hindu belief system.

\section{ABSTRAK}

Tulisan ini menguraikan sebuah praktik fikih keseharian atau lebih tepatnya praktik keislaman di kalangan minoritas muslim di Bali yang ditransformasi dalam bentuk keberagamaan yang adabtable dan mengedepankan kerukunan. Di tengah kuatnya dominasi tradisi Hindu dan tindakan sebagian ummat Islam di Indonesia yang melakukan kekerasan, masyarakat muslim Bali berupaya memanifestasi ajaran islam (fiqh) dalam keseharian yang toleran dan moderat. Melalui dua permasalahan seperti; Bagaimana pola adaptasi keberagamaan masyarakat muslim minoritas di Bali? Bagaimana masyarakat muslim membangun kerukunan antar ummat beragama sebagai manifestasi dari fikih kesehrian mereka? Penelitian ini mencoba menganalisisnya dengan teori maqashid syariah. Adapun untuk menopang perolehan datanya, tulisan ini menggunakan penelitian lapangan yang disertai dengan wawancara dan observasi. Berdasarkan kajian penulis, penelitian menunjukkan bahwa ada pola relasi sosial keberagamaan yang menarik yang terjadi dalam praktek keseharian minoritas muslim dalam mengekspresikan ajaran keislamannya di ruang publik. Umat Islam di Bali mampu melakukan aproriasi dalam menjalankan ajaran agamnya dan bisa beradaptasi dengan masyarakat sekitar yang secara sosio-antropologis didimonasi oleh sistem kepercayaan Hindu. 


\section{Pendahuluan}

Masyarakat muslim minoritas yang tinggal di sebuah daerah atau negara yang mayoritas non Islam tentu sedikit banyak akan mengalami kendala dan penyesuaian dalam menjalankan ajaran agamanya. Contohnya ketika mereka mau melaksanakan sholat jum'at tentu tidak semudah ketika tinggal di negara atau daerah yang mayoritas muslim dimana masjid akan begitu gampang diperoleh, begitu pula tentang makanan halal yang barangkali juga susah diperoleh. Tentu dalam kondisi yang demikian itu, fikih muslim yang minoritas mestinya berbeda dengan fikih muslim yang menjadi mayoritas.

Islam adalah agama yang welas asih (samhah) dan toleran (tasamuh). Oleh sebab itu, hukum Islam pun merujuk kepada prinsipprinsip tersebut. Dalam konteks penghormatan terhadap keyakinan agama lain, ajaran Islam sudah pernah diterapkan misalnya oleh Muhammad bin Qosim ketika menaklukkan India, ia mengharamkan tentaranya memakan daging sapi sebagai bentuk penghormatan terhadap orang India yang mayoritas Hindu dimana sapi adalah salah satu Dewa mereka. Begitu pula diceriterakan bahwa Sunan Kudus melarang muslim di Kudus waktu itu untuk menyembelih kurban berupa sapi sebagai bentuk toleransi terhadap masyarakat Kudus yang saat itu mayoritas Hindu atau Budha.

Keberadaan minoritas muslim di suatu daerah atau bahkan negara tentu memerlukan konsep fikih yang berbeda dengan fikih biasanya. Fikih tersebut lazim dikenal di era sekarang dengan sebutan fikih minoritas. Fikih minoritas adalah ketentuan-ketentuan hukum yang dirumuskan oleh para fuqaha berkaitan dengan perilaku umat Islam minoritas yang hidup di tengah-tengah masyarakat yang mayoritas non-muslim (Hasan \& Zuhri, 2014). Fikih minoritas ini muncul dan berkembang untuk merespon persoalan-persoalan yang dialami masyarakat muslim minoritas yang tinggal di sebuah negara atau wilayah non-muslim.

Fikih minoritas adalah upaya untuk menyeimbangkan antara komitmen keagamaan sebagai muslim dengan identitas sipilnya sebagai warga negara di dalam sebuah negara atau daerah yang mayoritas non-muslim. Menjadi muslim yang baik tidak harus mengorbankan status dan kewajiban kewarganegaraannya. Dua hal itu bisa dipadukan, pada satu sisi agama harus memahami kewarganegeraan umatnya, pada sisi lain, negara harus menghormati dan memberikan hak kepada kaum muslim untuk menjalankan syari'at-syari'atnya.

Istilah fikih minoritas sendiri baru berkembang dalam dua dasawarsa terakhir ini. Hal itu seiring dengan berdirinya organisasiorganisasi Islam dan yayasan-yayasan Islam yang memiliki kepedulian terhadap problemproblem muslim di Eropa dan Amerika Serikat. Beberapa tokoh yang merintis dan mengembangkan fikih minoritas ini antara lain Thaha Jabir al-Alwani, Yusuf alQaradhawi, dan Abdullah bin Bayyah (Hasan \& Zuhri, 2014). Oleh karena itu, secara disiplin keilmuan, fikih minoritas ini masih terbilang baru dan belum mapan. Fikih minoritas merupakan salah satu bentuk dari fiqh an-nawadzil yang mendesak untuk dibahas.

Dengan demikian, pembahasan dan penelitian fikih minoritas masih sangat dibutuhkan untuk melihat dan mendiskusikan model-model fikih minoritas di berbagai negara atau daerah. Oleh sebab itu, peneliti tertarik untuk melihat bentuk fikih minoritas yang dipraktekkan masyarakat muslim minoritas di Bali.

Dalam kaitan ini, untuk menjelaskan praktek fikih keseharian di kalangan muslim minoritas di Bali, penulis merancang pokok permasalahan sebagai acuan untuk mendeskripsikan dan menganalisis berbagai temuan di lapangan seperti; Bagaimana pola adaptasi keberagamaan masyarakat muslim minoritas di Bali? Bagaimana masyarakat muslim membangun kerukunan antar ummat beragama sebagai manifestasi dari fikih kesehrian mereka?

\section{Tinjauan Pustaka}

Kajian tentang fikih minoritas sudah banyak dilakukan oleh para akademisi dan peneliti yang menaruh perhatian serius terhadap kajian ini. Beberapa di antaranya tulisan tentang "Fiqh Minoritas: Fiqh AlAqalliyat dan Evolusi Maqashid A-Syari'ah dari Konsep ke Pendekatan" yang berupaya mereformulasi kajian fikih yang selama ini 
berkembang ditengah kehidupan masyarakat terutama kelompok minoritas muslim (Imam, 2010).

Fikih yang selama ini diyakini sebagai bentuk dan sumber hukum otentik dan baku, secar empiris atau setidak-tidaknya dalam pengalaman sebagian besar orang, seringkali kurang memberikan solusi yang tepat dan bahkan kurang memberikan jawaban yang jitu dalam merespon perubahan sosial kehidupan masyarakat, terutama yang berhubungan dengan pola hubungan antarumat beragama. bila mengacu pada berbagai pengalaman yang ada, kajian fikih yang diketengahkan oleh sebagian pengkaji maupun pelakunya selalu didasarkan pada kaidah masa lalu yang kurang adaptable dengan perkembangan zaman, dampaknya, banyak pandangan hukum Islam yang mengalami "kegagapan" ketika berhadapan dengan tuntutan zaman seperti bagaimana membangun kehidupan yang harmonis dan toleran antarumat beragama

Di samping itu, ada kajian senada yang diulas dalam "Fiqh Minoritas: Fatwa Kontemporer Terhadap Kehidupan Kaum Muslimin di Tengah Masyarakat Non Muslim" menjelaskan berbagai rujukan dan landasan naqliyah tentang fiqh minoritas yang menjadi perhatian dan ijtihad para ulamaulama fikih terdahulu. Bahkan, untuk mempertegas korelasi pemikiran para ulama terdahulu yang begitu concern juga dengan wacana fikih minoritas, buku ini memaparkan berbagai contoh penerapan untuk menjawab berbagai pertanyaan ummat Islam terutama yang tinggal di berbagai negara yang mayoritas menganut agama non-Islam, seperti agama Kristen, Katolik, Hindu, Budha, dan agama-agama lain (Qardlawi, 2004).

Dalam buku tersebut, ada 15 pertanyaan yang diurai secara apik dan menyentuh pada persoalan yang sangat mendasar dan bersifat keseharian. Misalkan tentang aqidah, ibadah, keluarga, makanan dan minuman, dan muamalah (interaksi sosial). Dari sekian pertanyaan yang menggambarkan aspek keseharian umat Islam yang ada di berbagai negara non-muslim tersebut, ada sebagian pandangan yang mencoba meneguhkan pandangan ulama terdahulu. Tapi ada pula yang menggambarkan ijtihadi Yusuf al Qaradlawi yang dalam beberapa sisi agak berbeda pemikiran dengan pandangan ulama terdahulu seperti ulama Jumhur.

Namun demikian, lepas dari perbedaan cara pandang Yusuf al Qaradlawi dengan para ulama terdahulu, yang jelas buku ini berupaya membangun sudut pandang hukum Islam lain untuk menyatakan bahwa fiqh minoritas merupakan sebuah solusi hukum dari pelbagai problematika kaum muslimin di wilayah minoritas, dengan berbagai kondisi yang mereka hadapi. Selain itu, Fiqh Minoritas merupakan representasi dari Fiqh Syar'i dan Fiqh Waqi'i ke dalam kehidupan sosial masyarakat muslim di wilayah minoritas.

Dalam konteks Indonesia, ada juga kajian tentang fikih yang responsif dengan kehidupan minoritas Muslim yang dibahas oleh para akademisi, peneliti, maupun aktivis keagamaan. Semisal buku yang disusun oleh aktivis organisasi kemasyarakatan seperti Nahdlatul Ulama (NU) yang ada di Bali dengan judul "Fikih Muslim Bali" (Maulana, 2017).

Buku ini berupaya menjelaskan dan menguraikan secara apik terkait sejarah perjalanan awal mula masuknya agama Islam di Bali pada abad XV. Di mana dalam proses penyebaran Islam di Bali dimulai dengan perjalanan perdagangan para pedagang muslim Cina, Arab dan Gujarat. Para pedagang tersebut cukup intens membangun hubungan diplomatik yang harmonis dengan para penguasa kerajaan Majapahit yang mempunyai hubungan baik dengan kerajaankerajaan Hindu Bali, khususnya kerajaan Gelgel Klungkung.

Selain itu, buku ini juga membahas kebiasaan dan adat masyarakat muslim Bali yang mempunyai kemiripan ciri khas terutama dalam kaitan hubungan ukhuwah dengan umat Hindu Bali. Ummat Islam, terutama yang afiliasi amaliah keislamannya yang bertaut dengan kelompok Islam nyang moderat dan menghargai tradisi keberagamaan seperti NU, yang cukup rajin membangun kegiataan keagamaan yang mengacu kepada tradisi lokal menjadi sebuah pendekatan budaya yang bisa menjalin hubungan tradisi dengan ummat Hindu yang dalam praktek keagamaannya juga banyak menautkan doktrinnya dengan kearifan lokal. Dari perjalinan ini kemudian keduanya tergerak untuk sama-sama membangun persaudaraan dengan tetap 
menjalankan ibadah agamanya masingmasing dengan baik. Selain itu, juga muncul kesadaran untuk menjaga harmoni serta keseimbangan antara hubungan vertikal dan horisontal dalam keyakinan religious.

Dalam kaitan ini, beberapa karya yang sudah membahas banyak hal tentang bagaimana merumuskan fikih minoritas sebagai jawaban terhadap realitas sosial kehidupan yang membentangkan fenomena hubungan antarummat beragama yang harus saling menghargai dan menghormati, dan karya yang membahas tentang bagaimana mempraktekkan rumusan fikih yang adequate dalam keseharian sehingga tidak memicu adanya resistensi melainkan harus mewujudkan ko-eksisten dan harmonisasi, menjadi sebuah pijakan bagi penulis untuk mengupas kajian yang sama. Namun demikian, ada pola fokus dan lokus yang agak berbeda dengan berbagai karya sebelumnya. Dengan mengacu kepada teori maqashid syariah, penelitian ini ingin menggambarkan dan menjelaskan praktek fikih keseharian muslim minoritas yang ada di Bali.

Secara epistemologis, maqashid asysyari'ah merupakan sebuah cara pandang atau cara berfikir dalam memahami ajaran Islam yang secara sistematis dikembangkan oleh Abu Ishaq asy-Syatibi. Al-Muwafaqat fi Ushul asy-Syari'ah merupakan karya Asy Syatibi menginspirasi banyak orang dalam memahami konsep maqashid syariah secara lebih mendalam (Abu Ishaq Asy-Syatibi, alMuwaffaqat Fi al-Ushul asy-Syariah, t.t: 4445). Dalam perkembangannya, konsep maqashid syariah dijadikan sebagai pisau analisis dalam memahami berbagai teks baik yang ada dalam al qur'an, hadits, maupun ajaran fiqh-fiqh klasik.

Pada era klasik, konsep maqashid asysyari'ah hanya bertumpu pada penjelasan mengenai tujuan syariah yaitu untuk kemaslahatan manusia yang diklasifikasikan ke dalam tiga kelompok, yaitu dlaruriyyat, hajiyyat dan tahsiniyyat. Dlaruriyyat terdiri atas lima prinsip yang harus dijaga yaitu 1) menjaga dan memelihara agama (hifzh addin), 2) menjaga dan memelihara jiwa (hifzh an-nafs), 3) menjaga dan memelihara akal (hifzh al-'aql), 4) menjaga dan memelihara keturunan (hifzh an-nasl), dan 5) menjaga dan memelihara harta (hifzh al-mal). Kelima bentuk kemaslahatan tersebut dikenal dengan istilah adl-dlaruriyyat al-khams (lima hal yang bersifat dlaruri) (Qardlawi, 2001).

Sedangkan, pada era kontemporer, konsep maqashid asy-syari'ah kemudian dikembangkan dan dikontekstualisasi sesuai dengan perkembangan zaman dan perubahan sosial oleh berbagai sarjana muslim, yang di antaranya Jasser Auda. Menurut Jaser Auda, maqashid adalah konsep-konsep moral yang merupakan prinsip hukum Islam, seperti, keadilan, martabat manusia, kehendak bebas, kemurahan hati, fasilitasi, dan kerja sama sosial. Nilai-nilai itu menggambarkan adanya keterkaitan antara hukum Islam dengan konsep tentang Hak Asasi Manusia saat ini, pembangunan, dan peradaban. Selain itu, maqashid syariah juga bisa digunakan untuk mengkaji isu seputar hak asasi manusia, sosial budaya, dan kehidupan antar umat beragam (Auda, 2008).

\begin{tabular}{lll}
\hline No & Teori Maqasid & \multicolumn{1}{c}{ Teori Maqasid } \\
& Klasik & Kontemporer \\
\hline 1 & Menjaga & Teori yang \\
& Keturunan (al- & berorientasi kepada \\
& Nasl) & perlindungan \\
& & Keluarga; \\
& & Kepedulian yang \\
& & lebih terhadap \\
& & institusi Keluarga. \\
\hline 2 & Menjaga Akal & Melipatgandakan \\
& (al-Aql) & pola pikir dan \\
& & research ilmiah; \\
& mengutamakan \\
& perjalanan untuk \\
& & mencari ilmu \\
& pengetahuan; \\
& & menekan pola pikir \\
& & yang \\
& mendahulukan \\
& & kriminalitas \\
& & kerumunan \\
& &
\end{tabular}




\begin{tabular}{|c|c|c|}
\hline & & $\begin{array}{l}\text { gerombolan; } \\
\text { menghindari upaya- } \\
\text { upaya untuk } \\
\text { meremehkan kerja } \\
\text { otak. }\end{array}$ \\
\hline 3 & $\begin{array}{l}\text { Menjaga } \\
\text { kehormatan; } \\
\text { menjaga jiwa } \\
(\text { al-'Irdh) }\end{array}$ & $\begin{array}{l}\text { Menjaga dan } \\
\text { melindungi } \\
\text { martabat } \\
\text { kemanusiaan; } \\
\text { menjaga dan } \\
\text { melindungi hak-hak } \\
\text { asasi manusia. }\end{array}$ \\
\hline 4 & $\begin{array}{l}\text { Menjaga agama } \\
\text { (al-Diin) }\end{array}$ & $\begin{array}{l}\text { Menjaga, } \\
\text { melindungi dan } \\
\text { menghormati } \\
\text { kebebasan } \\
\text { beragama dan } \\
\text { berkepercayaan. }\end{array}$ \\
\hline 5 & $\begin{array}{l}\text { Menjaga harta } \\
(\text { al-Maal) }\end{array}$ & $\begin{array}{l}\text { Mengutamakan } \\
\text { kepedulian sosial; } \\
\text { menaruh perhatian } \\
\text { pada pembangunan } \\
\text { dan pengembangan } \\
\text { ekonomi; } \\
\text { mendorong } \\
\text { kesejahteraan } \\
\text { manusia; } \\
\text { menghilangkan } \\
\text { jurang antara } \\
\text { miskin dan kaya. }\end{array}$ \\
\hline
\end{tabular}

Dalam kaitan ini, penafsiran dan pengembangan maqashid syariah yang dilakukan oleh Jasser Auda, menurut Amin Abdullah, menjadi pondasi pergeseran paradigma teori maqasid klasik menuju kontemporer yang sangat bermanfaat bagi pengembangan paham keislaman yang lebih inklusif dan kontekstual (Abdullah, 2012).
Seperti pembahasan dan telaah Jaser Auda tentang hifdz ad din (menjaga agama) yang dimaknai sebagai melindungi dan menghormati kebebasan beragama dan berkepercayaan.

Pemaknaan semacam ini, menjadi terobosan tersendiri yang bisa mengubah cara pandang baru atau ijtihad yang menyegarkan (fresh ijtihad) dalam membangun tradisi berfikih di era kontemporer. Termasuk bagaimana menjelaskan praktek fikih keseharian bagi pemeluk yang hidup di tengah-tengah masyarakat yang dalam posisi mayoritas maupun minoritas. Dalam kaitan ini, mengaproriasi praktek berfikih yang sesuai dengan realitas sosial, apalagi di era kontemporer, akan memberikan kemudahan dalam menginternalisasi spirit keberagamaan yang inklusif. (Abdullah, 2012).

Di samping itu, praktek berfikih yang fleksible dan adaptable, meminjam cara pandang Anas Ajiudin, akan menjadi modal sosial dalam menciptakan pluralisme yang ditandai dengan terbukanya ruang-ruang dialogis, kesetaraan, dan komitmen membangun konsensus sosial dalam masyarakat (Aijudin, 2017).

Dalam konteks Bali, di mana masyarat Islam menjadi kelompok minoritas dan secara kultural, sistem sosial yang terbangun di Bali didominasi oleh kepercayaan Hindu, tentu membutuhkan penyikapan yang elegan dan kosmopoitan agar tercipta kerukunan dan koeksistensi antar pemeluk agama. Meskipun, secara sosiologis, perlu ada penyesuaian diri yang harus dilakukan oleh umat Islam di Bali ketika ingin melaksanakan berbagai praktek keberagamaan maupun menjalin hubungan sosial dengan masyarakat.

Oleh karena itu, untuk mencermati lebih mendalam bagaimana umat Islam menjalani praktek keberagamaannya di Bali dan bagaimana cara umat Islam mengadaptasi diri dalam fikih kesehariannya di tengah masyarakat Bali yang secara antropologis didominasi oleh sistem kepercayaan Hindu, penelitian ini menggunakan teori maqashid syariah seperti yang dikembangkan oleh Jasser Audah dalam hal bagaimana manjaga agama (hifdz ad din) yang bermakna; membangun sikap adaptasi dan selalu memelihara kerukunan. 


\section{Metodologi Penelitian}

Penelitian ini merupakan penelitian kualitatif dengan jenis penelitian lapangan (field research) yaitu penelitian yang bertujuan melihat langsung praktek fikih keseharian masyarakat muslim minoritas di Bali kemudian ditarik ke dalam nash atau dasar-dasar dalam hukum Islam.

Untuk menjawab pokok permasalahan dalam penelitian ini, peneliti menggunakan pendekatan normatif-yuridis dengan kerangka teori maqashid asy-syari'ah terutama yang dikembangkan oleh Jasser Auda. Selain itu, untuk memperluas model analisis terhadap permasalahan yang ada di Bali penulis juga menggunakan pendekatan sosiologis yang meliputi teori Adaptasi dan akomodasi untuk menjelaskan bagaimana peran ummat Islam dalam mengaproriasi ajaran keislamannya yang inklusif guna mencapai tujuan yang lebih substansil yaitu kemaslahatan bersama (maslahah 'ammah).

Teknik pengumpulan data diperoleh dengan wawancara. Dalam wawancara ini kami menghimpun beberapa informan secara purposive yang dianggap mumpuni dan akuntabel dalam memberikan keterangan dan data yang kami butuhkan. Bahkan, untuk mengklarifikasi berbagai informasi yang penulis peroleh, penulis juga mencari informasi tambahan dan pandangan lain dari pihak lain untuk membandingkan antara informasi pertama dengan informasi lain secara obyektif.

Di samping itu, untuk semakin meyakinkan penulis terkait data-data yang penulis peroleh dari berbagai informan, penulis juga melakukan observasi langsung ke berbagai komunitas dan tempat ibadah untuk memverifikasi berbagai pandangan dan informan yang penulis wawancarai. Setidaknya, melalui observasi secara langsung ini penulis bisa memahami berbagai persoalan yang terjadi dalam praktek fikih keseharian mereka di tengah kehidupan masyarakat Bali yang didominasi oleh tradisi dan kepercayaan Hindu.

Data-data yang kami peroleh melalui wawancara dan observasi secara langsung, penulis melakukan analisis dengan model tahapan analisis data sebagaimana direkomendasikan Huberman dan Miles yaitu, data reduction, data display, dan conclusion drawing/verifying (Miles \& Huberman, 1994). Melalui tahapan analisis ini, penulis bisa memilah dan memilih berbagai informasi yang layak dijadikan sebagai bahan empiris yang akurat dan penulis jadikan sebagai acuan analisis untuk menghasilkan temuan menarik dari penelitian yang penulis lakukan.

\section{Hasil dan Diskusi}

Islam masuk ke Bali secara bergelombang. Gelombang paling awal diperkirakan dimulai pada abad ke-14. Kampung pertama yang didatangi muslim adalah Gelgel, kabupaten Klungkung. Generasi muslim awal yang tiba di Bali adalah para pengiring Dalem dari Majapahit yang berjumlah 40 orang. Itu terjadi pada masa pemerintahan Dalem Ketut Ngelesir, Raja Gelgel I (Kartini, 2017).

Gelombang berikutnya yaitu pada abad ke17, kali ini pelaut Bugis yang datang ke Bali untuk melakukan hubungan dagang. Dengan media perdagangan Islam disebarkan oleh orang Bugis kepada penduduk Bali. Puncak kedatangan orang Bugis ke Bali adalah apda tahun 1667 setelah terjadi perang Makassar yang memaksa orang-orang Bugis pergi ke luar Bugis untuk menghindari kejaran Belanda. Pelaut Bugis yang datang ke Bali kebanyakan mendarat di daerah Badung, Buleleng, dan Jembrana (Kartini, 2017).

Hingga hari ini kaum muslim tetap ada dan berkembang di Bali. Dari sembilan kabupaten/kota yang ada di Bali, umat Islam memiliki jumlah yang banyak bahkan mayoritas di tiga kabupaten yaitu kabupaten Jembrana, Buleleng, dan Karangasem. Di kota Denpasar, jumlah umat Islam juga lumayan banyak karena sebagai ibu kota Provinsi Bali, penduduknya plural dan banyak pendatangnya. Sisanya yaitu di kabupaten Badung, Bangli, Gianyar, Klungkung, dan Tabanan umat Islam minoritas.

Dalam kaitan ini, untuk mengetahui perkembangan umat Islam di Bali bisa dicermati dari sebaran tempat ibadah baik yang berbentuk masjid maupun mushalla. Melalui masjid dan mushalla ini umat Islam menunjukkan ekspresi keberagamaannya baik yang berhubungan dengan ketuhanan (ilahiyah) maupun antar manusia (basyariyah). Adapun data sebaran masjid dan mushala yang menjadi salah satu aras perkelindanan Jumlah dan karakteristik 
penduduk dengan tempat ibadah diperoleh dari kemenag Provinsi Bali seperti termaktub di bawah ini:

\begin{tabular}{lccc}
\hline \multirow{2}{*}{ Kota } & \multicolumn{3}{c}{ Jumlah Masjid } \\
\cline { 2 - 4 } & Raya & Agung & Besar \\
\hline Badung & - & 1 & 4 \\
\hline Bangli & - & 1 & 1 \\
\hline Buleleng & - & - & 4 \\
\hline Gianyar & - & 1 & - \\
\hline Jembrana & - & - & 3 \\
\hline Karangasem & - & - & - \\
\hline Klungkung & - & 1 & - \\
\hline Tabanan & - & 1 & 4 \\
\hline Denpasar & 1 & 1 & 4 \\
\hline Jumlah & 1 & 6 & 20 \\
\hline
\end{tabular}

\begin{tabular}{lccc}
\hline \multirow{2}{*}{ Kota } & \multicolumn{3}{c}{ Jumlah masjid } \\
\cline { 2 - 4 } & Jami & Bersejarah & $\begin{array}{c}\text { Di Tempat } \\
\text { Publik }\end{array}$ \\
\hline Badung & 6 & - & 5 \\
\hline Bangli & 1 & - & - \\
\hline Buleleng & 44 & 3 & 22 \\
\hline Gianyar & 3 & 2 & - \\
\hline Jembrana & 57 & 1 & 7 \\
\hline Karangasem & 28 & 2 & 1 \\
\hline Klungkung & 3 & 1 & - \\
\hline Tabanan & 8 & - & 11 \\
\hline Denpasar & 10 & 1 & \\
\hline Jumlah & 160 & 10 & \\
\hline & & & \\
\hline
\end{tabular}

Rekap data Masjid se Provinsi Bali (Kemenag Provinsi Bali, 2018)

\begin{tabular}{lrc}
\hline Kota & Musala & Masjid \\
\hline Badung & 76 & 92 \\
\hline Bangli & 7 & 10 \\
\hline
\end{tabular}

\begin{tabular}{lcl}
\hline Buleleng & 135 & 208 \\
\hline Gianyar & 12 & 18 \\
\hline Jembrana & 105 & 166 \\
\hline Karangasem & 27 & 64 \\
\hline Klungkung & 10 & 16 \\
\hline Tabanan & 21 & 34 \\
\hline Denpasar & 124 & 152 \\
\hline Jumlah & 517 & 760 \\
\hline
\end{tabular}

Rekap data Musala se Provinsi Bali (Kemenag Provinsi Bali, 2018)

Kemudian dari data masjid dan Musala tersebut, diketahui pula jumlah jamaah, imam, khotib dan muadzinnya.

\begin{tabular}{lcccc}
\hline \multirow{2}{*}{ Kota } & \multicolumn{2}{c}{ Jamaah } & \multicolumn{2}{c}{ Imam } \\
\cline { 2 - 5 } & Masjid & Musala & Masjid & Musala \\
\hline Badung & 19.236 & 6.725 & 66 & 44 \\
\hline Bangli & 1.850 & 186 & 9 & 17 \\
\hline Buleleng & 34.581 & 12.710 & 436 & 395 \\
\hline Gianyar & 2.150 & 1.590 & 25 & 36 \\
\hline Jembrana & 31.910 & 752 & 354 & 169 \\
\hline Karangasem & 19.370 & 701 & 170 & 74 \\
\hline Klungkung & 5.950 & 1.095 & 40 & 40 \\
\hline Tabanan & 5.850 & 2.785 & 57 & 65 \\
\hline Denpasar & 20.544 & 4.489 & 95 & 421 \\
\hline Jumlah & 141.441 & 51.033 & 1.252 & 1.261 \\
\hline
\end{tabular}

\begin{tabular}{lcccc}
\hline \multirow{2}{*}{ Kota } & \multicolumn{2}{c}{ Khotib } & \multicolumn{2}{c}{ Muazin } \\
\cline { 2 - 5 } & Masjid & Musala & Masjid & Musala \\
\hline Badung & 162 & 66 & 61 & 56 \\
\hline Bangli & 29 & 12 & 5 & 20 \\
\hline Buleleng & 534 & 20 & 1.057 & 463 \\
\hline Gianyar & 28 & 16 & 21 & 37 \\
\hline Jembrana & 332 & 6 & 305 & 159 \\
\hline Karangasem & 187 & 16 & 168 & 54 \\
\hline Klungkung & 88 & 52 & 19 & 28 \\
\hline Tabanan & 131 & 74 & 36 & 38 \\
\hline Denpasar & 349 & 544 & 81 & 248 \\
\hline Jumlah & 1.840 & 806 & 1.753 & 1.103 \\
\hline
\end{tabular}




\begin{tabular}{lll}
\hline \multirow{2}{*}{ Kota } & \multicolumn{2}{c}{ Remaja } \\
\cline { 2 - 3 } Basjid & \multicolumn{1}{c}{ Musala } \\
\hline Bangli & 541 & 364 \\
\hline Buleleng & 5.123 & 2.091 \\
\hline Gianyar & 77 & 50 \\
\hline Jembrana & 2.574 & 375 \\
\hline Karangasem & 3.148 & 178 \\
\hline Klungkung & 200 & 130 \\
\hline Tabanan & 360 & 335 \\
\hline Denpasar & 609 & 1.346 \\
\hline Jumlah & 12.699 & 4.869 \\
\hline Rekap data Jamaah & & - \\
\hline
\end{tabular}

Rekap data Jamaah, Imam, Khotib, Muazin, dan Remaja (Kemenag Provinsi Bali, 2018)

Dalam hal ini, sebaran tempat ibadah yang setiap waktu menunjukkan perkembangannya tentu bukan berarti meniscayakan umat Islam harus bebas menjalankan aktifitas sosial keberagamannya dengan tanpa kompromi dengan masyarakat sekitar. Sebab, secara sosiologis, disadari atau tidak, kultur masyarakat Bali masih didominasi oleh tradisi Hindu. Dimana, di berbagai lini kehidupan sosial yang berlangsung di Bali lebih banyak diwarnai oleh atmosfir ke-Hinduan yang sarat dengan pernak-pernik animism dan dnamism.

Oleh karena itu, ada beberapa langkah yang harus dilakukan umat Islam agar satu sisi bisa menjalankan aktifitas keagamaannya di berbagai tempat ibadah secara aman dan nyaman. Namun di sisi lain nuansa keberagamaannya perlu menjadi aura sosial yang mencerahkan lingkup kehidupan yang lebih besar. Dalam kaitan ini, pemaknaan hifdz ad din yang dijabarkan oleh Jaser Auda harus menjadi pintu masuk bagaimana membingkai praktek berfikih dalam kesehariannya.

Meminjam cara pandang Ahmad Imam Mawardi ada empat model bagaimana umat Islam sebagai kaum minoritas dalam memposisikan diri di bali yang secara mayoritas dilingkupi oleh traduisi kehinduan. Pertama, asimilasi yaitu suatu kondisi dimana minoritas meninggalkan identitas kulturalnya dan kemudian secara total beradaptasi dan melebur pada budaya mayoritas. Kedua, overlapping adalah model kebalikannya yaitu peniscayaan perubahan fundamental budaya asal untuk menerima budaya pendatang minoritas. Ketiga, segregasi adalah sebuah model dimana kelompok asal dan kelompok pendatang sama-sama hidup terpisah dan hidup dengan identitas kulturalnya masingmasing. Keempat, adalah model dimana penduduk asal dan pendatang hidup bersama, membangun komunikasi bersama, dan membiarkan perubahan terjadi secara alami bersama perjalanan sejarah kehidupan mereka (Imam, 2010).

Keempat aspek ini merupakan cara dan pendekatan yang paling realistis bisa dilakukan oleh umat Islam agar umat Islam bisa menjalankan ajaran agamanya dengan baik dan tidak menimbulkan persitegangan dengan masyarakat sekitar. Sebab, keempat aspek tersebut menjadi sebuah realitas sosial yang direkonstruksi oleh umat Islam menjalankan fikih kesehariannya, baik dalam hal peribadatan, muamalah, dan lain sebagainya.

Secara sosiologis, keempat aspek ini menjadi cara humanis dalam mendialektikakan praktek keberagamaan dengan aktifitas keseharian umat Islam. Setidaknya, model dialektika ini menjadi rumusan berfikih yang lazim dilakukan oleh sebuah komunitas yang secara demografis menjadi posisi yang minoritas. Setidaknya, dengan cara tersebut, merujuk pandangan Peter L Berger dan Thomas Luckman, umat Islam akan bisa menjalankan fikih kesehariannya dengan tahapan eksternalisasi, objektifikasi, dan internalisasi (Berger \& Luckman, 2012).

Melalui tahap eksternalisasi, umat Islam bisa mengejawantahkan ajaran agamanya dalam keseharian sesuai dengan apa yang diyakini. Dengan kontur masyarakat Bali yang mayoritas penganut Hindu, diperlukan penyesuaian diri oleh umat Islam yang minoriotas dalam mempraktekkan fikih kesehariannya sesuai dengan iklim sosial yang ada. Dalam kaitan ini, ketika umat Islam bisa menekan egosime doktrinal dengan cara mencairkan praktek berfikihnya dengan fleksible, maka setiap ajaran agama yang diekspresikan akan menjadi sebuah kebiasaan atau teladan sosial yang secara objektif akan diikuti oleh umat Islam lain. Pada gilirannya, ketika spirit keberagamaan dan praktek berfikih umat Islam berada pada titik kosmis 
yang elegan dan humanis, maka tahap berikutnya umat Islam akan mampu internalisasi niai-nilai keagamaan secara inklusif dan selalu berupaya menjadikan tempat ibadahnya sebagai sumber inspirasi.

Pada akhirnya, fleksibilitas umat Islam di Bali dalam menjalankan ajaran agama dan melakoni praktik berfikihnya secara elegan akan berkontribusi dalam penyerbukan modal sosial keberagamaan yang satu sisi meneguhkan cara beradaptasi diri dengan masyarakat sekitar sekaligus menjunjung tinggi spirit kerukunan yang menjadi the ultimate concern bagi semua pemeluk agama.

Dalam kaitan ini, untuk mengetahui lebih gambalang bagaimana pola adaptasi dilakukan oleh umat Islam di Bali, di bawah ini akan diuraikan dinamika adaptasi yang berlangsung hingga saat ini sehingga umat Islam bisa eksis di daerah Bali.

\section{a. Pola Adaptasi}

Masyarakat minoritas muslim di Bali dalam menjalankan dan mempraktekkan ajaran agamanya dalam beberapa hal mungkin tidak sama dengan muslim yang tinggal di daerah mayoritas berpenduduk muslim. Sedikit banyak ada hambatan-hambatan yang ditemui. Salah satu contohnya adalah makanan halal, sholat jum'at atau berjemaah di masjid yang letaknya cukup jauh dari rumah, dan lain-lain.

Namun demikian, hambatan-hambatan itu tidak terlalu dirasakan oleh masyarakat minoritas muslim di Bali karena mereka mampu beradaptasi dengan masyarakat dan budaya yang ada di Bali, bahkan dalam level tertentu, umat Islam di Bali sudah mampu melakukan asimilasi dan akulturasi dengan budaya Bali.

Secara umum, definisi adaptasi adalah cara bagaimana organisme mengatasi tekanan lingkungan sekitarnya untuk bertahan hidup. Organisme yang mampu beradaptasi terhadap lingkungannya mampu untuk memperoleh air, udara dan nutrisi (makanan), mengatasi kondisi fisik lingkungan seperti temperatur, cahaya dan panas. Adaptasi yang dipakai di dalam penelitian ini lebih condong kepada adaptasi budaya.

Menurut Young Yun Kim, yang dimaksud dengan adaptasi budaya adalah proses jangka panjang yang dilakukan oleh individu untuk menyesuaikan diri dengan lingkungannya melalui pembelajaran dan pertukaran komunikatif hingga dirinya merasa nyaman di lingkungan yang baru. Teori adaptasi budaya dirumuskan oleh Kim untuk menggambarkan proses adaptasi budaya dan menjelaskan struktur proses adaptasi budaya serta berbagai variabel penting yang mempengaruhi tingkatan dimana seseorang kemudian mengadaptasi budaya baru dan budaya yang tidak dikenal (Kim, 2001).

Pola adaptasi yang dilakukan oleh masyarakat muslim Bali bisa dalam bentuk adaptasi budaya, arsitektur tempat ibadah, dan bahkan pada level tertentu adalah cara dan ritual peribadatan. Proses adaptasi sebenarnya tidak hanya dilakukan oleh sepihak tapi oleh kedua belah pihak. Dengan kata lain, sistem religi Islam dan budaya umat Islam bisa beradaptasi dengan budaya lokal Bali, pada saat yang bersamaan sebetulnya budaya lokal Bali juga sedang beradaptasi dengan sistem religi dan budaya Islam. Jadi dalam konteks ini ada proses saling meminjam atau silang budaya (Napsiah, 2019).

I Made Pageh dalam penelitiannya menyebutkan bahwa terdapat jejak sejarah mengenai integrasi antarumat di Bali. Pura Kartanegara (Gambur Angalayang) menurutnya adalah tempat ibadah integartif antara etnik dan keyakinan. Artinya di satu tempat ibadah, beragam etnis dan keyakinan bisa melakukan ritual di tempat yang sama. Begitu pula bentuk Pelinggih Ratu Mekah yang berada dalam satu tempat pemujaan dengan sistem religi lainnya, dengan susunan sebagai berikut: (1) Palinggih Ratu Sundawan, untuk orang Sunda; (2) Palinggih Ratu Ayu Subandar, untuk orang Cina; (3) Palinggih Ratu Dalem Mekah, untuk orang Islam-Mekah; (4) Palinggih Ratu Melayu, untuk orang Melayu; (5) Palinggih Ratu Dalem Pingit (Raja Bali Aga) (Pageh, 2018).

Menurut I Made Pageh, kearifan lokal masyarakat Bali sudah terbentuk sejak abad ke-12 melalui perdagangan dan persembahyangan bersama di satu lokasi sesuai dengan agama dan kepercayaannya masing-masing. Palinggih Ratu Sundawan mengacu kepada Sunda Jawa Barat dengan Sunda Kawiwitannya, Ratu Ayu Subandar mengacu kepada Cina (Buddha), Ratu Dalem Mekah mengacu kepada Mekah asal Islam, 
Ratu Melayu mengacu kepada orang Melayu dan Palinggih Dalem Pingit mengacu kepada raja Bali Aga (Pageh, 2018).

Dalam kaitan ini, temuan I Made Pageh semakin terkonfirmasi ketika penulis melakukan penelitian ke Bali. Penulis melihat secara langsung dua lokasi kompleks tempat ibadah yang dibangun secara berdekatan di sebuah area yang sama. Kedua lokasi itu adalah Puja Mandala dan kawasan Masjid Palapa. Kawasan Puja Mandala memiliki 5 tempat ibadah yang saling berdampingan, yaitu: Masjid Agung Ibnu Batutah, Gereja Katolik Maria Bunda Segala Bangsa, Gereja Kristen Protestan di Bali jemaat Bukit Doa, Vihara Buddha Guna, dan Pura Jagatnatha.

Begitu pula kawasan Masjid Palapa, sebuah masjid megah yang dibangun oleh Tommy Soeharto di kawasan selatan Bali tepatnya daerah Pecatu. Masjid ini dibangun secara berdekatan bahkan seakan tanpa jarak dengan tempat ibadah lainnya. Meskipun masjid ini termasuk kategori masjid sebagai fasilitas publik karena berada di kawasan wisata, tetapi tidak bisa dipungkiri bahwa itu adalah wujud toleransi di Bali yang sudah berada pada tingkat yang matang.

Akulturasi muslim Bali dengan budaya Bali misalnya bisa kita lihat pada bentuk bangunan beberapa masjid yang ada di Bali, salah satu contohnya adalah Masjid Al-Qomar di Denpasar. Masjid ini dibangun di atas lahan seluas 5,9 are dengan luas bangunan 3,5 are, Masjid Al-Qomar tampak megah nan artistik. Masjid Al-Qomar berada di ujung Jalan Pura Demak Banjar Buagan, Denpasar Barat, Kota Denpasar. Awalnya masjid ini adalah musolla yang kemudian berkembang dan dibangun lebih luas lagi menjadi sebuah masjid $(\mathrm{H}$. Supandi, 2018).

Yang menarik dari masjid ini adalah arsitekturnya, karena arsitektur masjid AlQomar dibangun dengan arsitektur Bali yang kental. Masjid ini tidak hanya menjadi tempat beribadah umat Islam, tetapi ia lebih jauh menjadi simbol Menyama Braya antarumat beragama atau simbol harmonisasi hubungan antarumat beragama.

Tidak hanya dalam arsitektur tempat ibadah, akulturasi juga terjadi pada bidang seni dan budaya antara agama Islam dan Hindu di Bali. Prof Drs H Shaleh Saidi, Guru
Besar Fakultas Sastra Universitas Udayana, pernah mengungkapkan bahwa terdapat buku dan geguritan (pembacaan ayat-ayat suci Hindu) yang ternyata di dalamnya mengandung unsur nuansa Islam. Bukti lainnya adalah di Desa Pegayaman-Buleleng, Kepaon-Denpasar, serta Desa Loloan Di Jembrana. Di desa Pegayaman misalnya sebagian besar warganya memeluk agama Islam, namun nama depan sebagian besar warganya sama seperti orang Bali pada umumnya, sehingga muncul nama seperti misal Wayan Muhammad Saleh atau Made Jalaluddin (Bali Post, 2001).

Lembaga adat yang tumbuh di masyarakat muslim Bali juga sama dengan lembaga adat masyarakat Bali Hindu. Dalam pengairan bidang pertanian tradisional (Subak) misalnya, umat muslim juga menerapkan cara dan pola pengaturan air seperti yang dilakukan petani yang beragama Hindu, meskipun cara mensyukuri saat panen berbeda.

Toleransi dan kerukunan yang terjadi di Bali bukanlah sesuatu yang instant, tapi sudah melalui proses yang panjang sejak abad ke-15 yang lalu. Sekarang aktor-aktor toleransi dan kerukunan di Bali dilakukan oleh komunitaskomunitas dan kelompok - kelompok keagamaan yang asosiatif dan tidak ideologis sebagaimana dijelaskan sebelumnya.

Sayangnya, toleransi dan kerukunan ini pernah ternoda dengan terjadinya Bom Bali I dan II yang menelan banyak korban. Sedikit banyak peristiwa tersebut berpengaruh terhadap hubungan harmonis antara muslim dan Hindu di Bali. Masih ingat pasca peristiwa kelam itu, orang Bali menolak kedatangan orang Jawa (Lamongan tempat asal Amrozi cs) ke Bali.

Belakangan kemunculan dan kedatangan kelompok ekstrem baik di kalangan Hindu maupun Islam juga mengganggu hubungan baik yang sudah susah payah dibangun generasi pendahulunya. Di kalangan Hindu muncul kelompok ekstrem yang dikomandani Arya Wedakarna (Arya Wedakarna, 2018). Menurutnya:

Arya Wedakarna adalah seorang dosen dan tokoh Hindu yang sering memprovokasi dan tidak simpati terhadap umat Islam di Bali. 
Untungnya, kelompok Wedakarna ini tidak besar dan tidak banyak jumlah pengikutnya.

Tak terkecuali kedatangan kelompok ekstrem muslim yang berafiliasi dengan kelompok Wahabi (Pegawai Kemenag, 2018).

Kelompok Wahabi ini sering membuat masalah, mereka tidak mau solat di masjid yang dekat rumahnya apabila amaliah di masjid itu tidak sesuai dengan ajaran kelompoknya. Dia akan melaksanakan solat di masjid yang jauh asal sama atau mirip dengan ideologi kelompoknya. Model beragama mereka yang seperti itu akhirnya membuat mereka berusaha merebut masjid dan kemudian dijadikan home base kegiatan ideologi kelompoknya. Masjid yang berhasil dikuasai adalah masjid raya Denpasar, oleh karena itu, menurut sumber ini, masjid raya Denpasar akan dipindah ke masjid lain yang masih netral.

Sedikit banyak dampak Bom Bali I dan II masih dirasakan terutama oleh masyarakat asli Bali, namun demikian, seiring dengan kuatnya persaudaraan yang sudah lama dibangun oleh masyarakat Bali dengan semua latar belakang etnis dan agamanya, hambatan itu perlahan tapi pasti dapat diatasi. Alhamdulillah selama peneliti melakukan penelitian di pulau Dewata ini tidak pernah memperoleh perlakuan yang tidak menyenangkan baik oleh kaum muslim maupun oleh terutama kaum Hindu.

Namun demikian, masalah tersebut bukan berarti memupus potret kehidupan masyarakat Bali yang selama ini mampu menunjukkan pola ke-salingan (interchange) secara simbiosis. Hal ini terbukti dalam sikap antar pemeluk agama, terutama umat Islam yang bisa memposisi diri secara adaptif dan akomodatif. Keberadaan umat Islam yang selama ini lebih mengedepankan spirit kemaslahatan bersama dan menekan egodoktrinalnya dalam menjalankan fikih kesehariannya berdampak positif pada terwujudnya kerukunan (Junaidi, 2018).

Apalagi, secara historis, kerukunan menjadi sebuah keniscayaan sosio-kultural yang dilakukan oleh para pendahulunya. Untuk mengetahui lebih detail bagaimana potret kerukunan yang sejak dahulu sudah berlangsung dan bertahan hingga saat ini, di bawah ini akan diuraikan potret kerukunan antar umat beragama yang berlangsung di Bali.

\section{b. Wujud Kerukunan}

Kerukunan antar umat beragama di Bali sudah tercipta sejak abad XIV dan XVI ketika kerajaan-kerajaan Hindu di Bali seperti kerajaan Gelgel Klungkung, Kerajaan Pemecutan (Badung) dan Kerajaan Buleleng memiliki banyak pengiring dan prajurit muslim. Sebagai bentuk penghargaan kepada kaum muslim yang telah taat dan mengabdi kepada kerajaan-kerajaan Hindu Bali, maka Kerajaan Hindu Bali mengizinkan dan bahkan memberikan hadiah kawasan khusus untuk dihuni dan ditinggali kaum muslim. Gelgel dan Kepaon adalah salah satu tanah pemberian raja-raja Hindu di Bali kepada umat Islam.

Hubungan harmonis itu terus dibina dan dilanjutkan oleh generasi-generasi penerusnya. Tidak heran saat ini kita masih bisa menyaksikan bentuk-bentuk kerukunan tersebut dalam kehidupan nyata sehari-hari masyarakat Bali. Ketika hari raya Nyepi, Galungan, Kuningan, tidak hanya masyarakat Hindu di Bali yang ikut berbahagia menyambutnya, tetapi kaum muslim pun ikut pula berpartisipasi secara sosial, semisal ikut menjaga keamananan, saling berkunjung, saling menjamu dan saling tukar hadiah. Masyarakat Hindu juga menghormati muslim yang berkunjung ke rumahnya dengan tidak menyuguhkan makanan daging babi yang haram bagi kaum muslim (Amrullah, 2018).

Ketika hari raya Nyepi, dimana dilarang tiga hal yaitu bekerja, menyalakan api (lampu) dan bepergian. Masyarakat muslim juga harus menghormatinya dengan tidak menghidupkan lampu (kalaupun menghidupkan lampu tetapi semua jendela dan lubang-lubang rumahnya harus ditutup agar supaya cahaya lampu tersebut tidak keluar). Begitu pula ketika hari raya Nyepi jatuh pada hari Jum'at, umat muslim juga menghormatinya dengan tidak datang ke masjid dengan kendaraan bermotor (jalan kaki), tidak memukul bedug, tidak menggunakan pengeras suara.

Sebaliknya ketika umat Islam mau merayakan hari raya atau melaksanakan PHBI, lapangan yang biasanya dipakai untuk perayaan umat Hindu diijinkan untuk dipakai umat Islam bahkan para pecalang 
(pengamanan adat) ikut mengamankan sehingga suasana aman, damai, dan khusyuk dalam beribadah dapat tercapai (I Made Ketut, 2018).

Di Bali minoritas muslim lebih mengedepankan substansi daripada formalitas, karena itu yang diutamakan adalah nilai-nilai kearifan lokal atau pada level tertentu mereka menerapkan margin of appreciation. Contohnya pasca Bom Bali I dan II masyarakat Hindu Bali agak trauma dengan 'masjid'. Dengan demikian, ketika ada kelompok muslim berkeinginan untuk mendirikan masjid, hal itu menjadi masalah. Namun jika umat Islam mau mendirikan musolla tidak dipersoalkan. Dalam hal ini berlaku kaidah maa laa yudraku kulluhu la yutraku kulluhu, sesuatu yang tidak dapat diperoleh seluruhnya, maka jangan ditinggalkan seluruhnya. Nama masjid atau musolla sama saja, yang penting bisa dibuat untuk tempat beribadah umat Islam.

Saling berkunjung ketika umat Islam merayakan iedul fitri atau ketika umat Hindu merayakan Galungan, Kuningan atau Nyepi bagi umat Islam Bali ini hanyalah kegiatan sosial, bukan pertukaran akidah dan keyakinan. Artinya ketika umat Islam berkunjung kepada saudaranya sesama masyarakat Bali yang beragama Hindu tidak kemudian menjadikan mereka murtad dari agamanya. Itu hanyalah salah satu usaha menjaga relasi kohesitas sosial (Saifurrahman, 2018).

Dalam interrelasi sosial keberagamaan dan praktek pluralism yang begitu cair tersebut, umat Islam di Bali bisa menempatkan diri dengan baik dan selalu mengedepankan spirit kerukunan dalam bermasyarakat. Meskipun beberapa waktu, Majlis Ulama Indonesi pernah mengeluarkan fatwa keharaman pluralism tidak pernah diacuhkan oleh umat Islam di Bali. Sebab, bagi umat Islam di Bali, praktek pluralism sebatas dimanifestasikan dalam kegiatan kemanusiaan seperti saling berkunjung, saling menjamu, saling membantu, dan semacamnya. Selain itu, dalam pandangan umat Islam di Bali, fatwa tersebut justru lebih berdampak kepada eksklusifitas beragama dan tindakan segregasi yang bisa memicu keretakan sosial.

Padahal kekuatan pemersatu yang ada pada masyarakat majemuk adalah pola kohesifitas sosialnya yang erat. Maka, di kalangan umat muslim yang ada di Bali, dalam perspektif maqashid syariah, mengedepankan sikap beradaptasi dengan lingkungan sekitar dan selalu berikhtiar untuk menjujung spirit kerukunan adalah etika sosial keberagamaan yang selalu dilakukan. Atau dalam bahasa kaidah fikih yang lazim dijadikan sandaran berfikih secara inklusif adalah: idza ta'aradlal maslahatani quddimat a'dzamu fihima bi al irtikabi anfa'u fihima.

Dampak positifinya, meminjam analisis Haryanto, upaya tersebut menunjukkan sebuah komitmen di kalangan mereka untuk selalu mempraktek fikih keseharian demi terwujudnya kenyamanan dalam beragama dan secara eksternal bisa beradaptasi dengan masyarakat yang beda agama secara konseptual (Haryanto, 2015).

\section{Kesimpulan}

Dari berbagai uraian di atas, penulis mencoba memperjelas beberapa temuan dan data fikih keseharian minoritas muslim di Bali dengan dua bagian.

Pertama, pola keberagamaan masyarakat muslim minoritas di Bali cukup dinamis dan kondusif. Mesipun secara kultural masyarakat Bali didominasi oleh tradisi agama Hindu bukan berarti masyarakat Bali menguasai peran-peran keberagamaan yang membuat agama lain mengalami kesulitan. Akan tetapi, ada asas saling pengertian dan sikap saling menghargai yang dilakukan oleh masingmaisng ummat beragama, terutama ummat Islam. Berdasarkan asas saling menghargai tersebut, maka implementasi keberislaman baik dalam konteks ibadah mahdlah maupun muamalah tidak mengalami hambatan yang berarti. Meskipun, dalam proses terjadi beberapa gesekan disebabkan oleh mispersepsi dan miskomunikasi antar dua belah pihak yang kadang ditimbulkan dari isu-isu sensitifitas dari laur Bali maupun kasus Bom yang terjadi di Bali.

Kedua, untuk mewujudkan pola keberagamaan yang kondusif dan harmonis baik di kalangan internal ummat Islam maupun dalam hubungan antarumat beragama di Bali, umat Islam melakukan tindakan adaptasi dan akomodasi dalam praktek berfikihnya. Di antara bentuk akomodasinya adalah, umat Islam mengerangkai cara 
berfikir yang taktis dan cara pandang yang adaptif dalam menyampaikan ajaran Islam. Terutama, bagaimana melakukan kontekstualisasi ajaran Islam yang bersumber kepada al qur'an, hadits, dan rumusanrumusan fikih yang dipegangi sebagai dalil naqli dalam menjalankan ajaran Islam. Dengan demikian, pola penyajian agama yang berangkat dari berbagai dalil naqli mampu dinarasikan dan dideskripsikan sesuai dengan realitas sosial yang ada. Berangakat dari cara penalaran keislaman yang akomodatif terhadap khazanah lokalitas dan responsive dengan tuntutan kontekstualisasi dalil-dalil naqli yang menunjang bagi tumbuhnya corak kehidupan yang harmonis dan toleran, maka ummat Islam yang ada di Bali bisa menjalankan praktek keberagamaannya, baik dalam konteks ibadah mahdlah maupun muamalah dengan kondusif dan menyejukkan.

\section{Daftar Pustaka}

Abdullah, A. (2012). Epistemologi Keilmuan Studi Hukum Islam di era GlobalisasiMultikultural. Dipresentasikan pada Seminar Nasional "Rekonstruksi dan Paradigma Keilmuan dalam Pengembangan Keilmuan Fakultas Syari'ah dan Hukum," UIN Sunan Kalijaga.

Aijudin, A. (2017). Mengelola Pluralismemelalui Dialog Antar Agama (Sebuah Tinjauan Teoritik) Managing Pluralismthrough Interfaith Dialogue (A Theoretical Review). Jurnal SMART (Studi Masyarakat, Religi, dan Tradisi), 3(1), 119-124.

https://doi.org/10.18784/smart.v3i1.493

Amrullah, A. (2018). Wawancara.

Arya Wedakarna. (2018). Wawancara.

Auda, J. (2008). Maqashid al-Syariah As Philasophy of Islamic Law; a Systems Approach. Amerika: The International Institute of Islamic Thought.

Bali Post. (2001).

Berger, P. L., \& Luckman, T. (2012). Tafsir Sosial Atas Kenyataan: Risalah tentang Sosiologi Pengetahuan. Jakarta: LP3ES.
Haryanto, J. T. (2015). Relasi Agama Dan Budaya Dalam Hubungan Intern Umat Islam. Jurnal SMART (Studi Masyarakat, Religi, dan Tradisi), 1(1). https://doi.org/10.18784/smart.v1i1.228

Hasan, N., \& Zuhri. (2014). Modul Pelatihan Fiqh dan HAM. Lkis Pelangi Aksara.

I Made Ketut. (2018). Wawancara.

Imam, M. A. (2010). Fiqh Minoritas: Fiqh AlAqalliyat dan Evolusi Maqashid ASyari'ah dari Konsep ke Pendekatan. Yogyakarta: LKis.

Junaidi, A. (2018). Wawancara.

Kartini, I. (2017). Dinamika Kehidupan Minoritas Muslim Di Bali. Masyarakat Indonesia, $37(2)$, $115-145$. https://doi.org/10.14203/jmi.v37i2.635

Kim, Y. Y. (2001). Becoming Intercultural: An Integrative Communication Theory and Cross Cultural Adaptation. USA: Sage Publication.

Maulana, M. T. (2017). Fikih Muslim Bali. Yogyakarta: Razka Pustaka.

Miles, M. B., \& Huberman, A. M. (1994). Qualitative Data Analysis: A Sourcebook of New Method. Terjemahan Tjetjep Rohendi Rohidi. Analisis Data Kualitatif: Buku Sumber tentang Metode-metode Baru. Jakarta: Universitas Indonesia (UI-PRESS).

Napsiah. (2019). Modal Sosial Sebagai Penguatan Identitas Sosial Masyarakat Muslm Di Bali. Jurnal SMART (Studi Masyarakat, Religi, dan Tradisi), 5(1), 101-111. https://doi.org/10.18784/smart.v5i1.740

Pageh, I. M. (2018). Kearifan Sistem Religi Lokal dalam Mengintegrasikan Umat HinduIslam di Bali. Jurnal Sejarah Citra Lekha, $3(2)$, 88-98. https://doi.org/10.14710/jscl.v3i2.19411

Pegawai Kemenag. (2018). Wawancara.

Qardlawi, Y. A. (2001). Ri'ayat al-Biah fi Syari'at al-Islam. Cairo: Dar asy-Syuruq.

H. Supandi. (2018). Wawancara. 
Qardlawi, Y. A. (2004). Fiqh Minoritas: Fatwa Kontemporer Terhadap Kehidupan Kaum Muslimin di Tengah Masyarakat Non Muslim. Jakarta: Zikrul Media.
Saifurrahman. (2018). Wawancara. 